Vol. 8, No. 1, 2021

https://doi.org/10.23939/eem2021.01.043

UDC 658:338: 65.012.8

JEL Classification Code: M 41

\author{
O. Grytsay \\ Lviv Polytechnic National University, Ukraine, PhD, Associate Professor \\ E-mail: olga.i.grytsay@1pnu.ua \\ ORCID: 0000-0001-6305-9219
}

M. Pankiv

Lviv Polytechnic National University, Ukraine, master

E-mail: mariana.pankiv.mopz.2020@lpnu.ua

ORCID: 0000-0002-2918-3440

D. Kut
Lviv Polytechnic National University, Ukraine, bachelor
E-mail: dinakut@ukr.net

G. Wojtan

Maria Curie-Sklodowska University, Poland, master

E-mail: gabriella8991@o2.pl

\title{
ANALYSIS OF THE ENTERPRISE OPERATING EXPENSES AND WAYS OF IMPROVEMENT OF THEIR ACCOUNTING
}

\begin{abstract}
Activities of industrial enterprises are associated with continuous consumption of certain types of resources, so expense accounting plays a crucial role in determining the enterprise efficiency. Accounting procedures occupy a key place in information support system of any enterprise, since the original information on the enterprise activities in the form of financial statements and internal documentation (source documents, journals and ledgers) is essential in order to meet the needs of internal and external users. It is particularly important to account for operating expenses, which forms information about the use of materials, labor and other resources involved in the production process. Properly organized accounting and analytical information on operating expense ensures fair and accurate assessment of the enterprise production process and provide effective management decision-making. The purpose of the scientific paper is to analyze operating expenses, organization and methodology of the accounting process at the enterprise and to develop practical recommendations for improving the accounting for operating activity.This
\end{abstract}

goal necessitates the solution of the following tasks: determine the nature and classification of operating expenses; analyze the dynamics and structure of operating expenses; develop the suggestions concerning the improvement of registration-analytical information of operating expenses. The used research methods and general characteristics of paper. The authors applied the method of literature review to justify the relevance of the chosen research topic. On the basis of the comparative method the main economic indicators of activity, in particular dynamics and structure of operating expenses according economic elements and according items of calculation were defined. On the basis of system analysis and synthesis, proposals on the composition of items of production costing and on the introduction of classification of expenses by groups in terms of relevant items of general production expenses, administrative, marketing expenses and other operating expenses were formed.

Key words: operating expenses, revenue, financial result, analysis, accounting. 


\section{Introduction}

One of the most important objects in the enterprise management system is the process of accounting for operating expenses in general and in the context of their types, purposes, periods during which they were incurred. Regardless of the enterprise industry, ownership and other factors expenses could be considered as key elements in the enterprise operation, as they directly affect its profitability and further development.

Scholars have paid significant attention to the impact of accounting policies on the accounting and financial reporting of the enterprise. Analysis of recent research and publications allows us to conclude that the extent to which the enterprise will have information about its operating expenses depends on its development and success. However, in most cases, researches are aimed at solving problematic issues of cost management in general (Deriy, V. [1], Didorenko, T. [2], Ovcharuk, V. [3], Kostyrko, R. [4], Milash, I. [5]) or only the expenses of the subject of a particular type of economic activity (Denisyuk O.M. [6], Pavelko O. V. [7], Hnylytska, L. [8], Shatalkin, I. [9]). Accounting for enterprise operating expenses, which have a direct impact on determining the financial results of the reporting period, needs further improvement.

The objectives of the research are to study the essence of operating expenses, to analyze their dynamics and structure on the example of a particular enterprise, as well as provide suggestions for improving the accounting and analytical information of the studied expenses.

\section{Presentation of basic material of the research}

The expenses of the enterprise are classified depending on the type of activity: operating, financial

\section{Analysis of recent research and publications}

and investment. Operating activities are the core activities of an enterprise that include transactions related to the production, sales and management of the enterprise.

Considering the production process in value terms, "at the entrance" to the system the elements of production consumption are reflected, i.e. expenses, and "at the exit" - the finished products.

Thus, operating expenses are the resources used in connection with the main activity of the enterprise aimed at the production and sale of products (goods, works, services), which is the key purpose of the enterprise and constitute the main share of its revenue), as well as transactions that provide it or caused by this activity [1 Denisyuk O. M.].

Operating expenses are usually continuous, ongoing and are necessary to support the production process and business administration.

To analyze operating expenses, the organization and methodology of their accounting process and develop practical recommendations for improving the accounting for operating expenses, LLC "Lviv Center for Development and Protection of Economic Entities" was selected. It is an enterprise that engages in making brick from burnt clay. For such type of operation, an enterprise is equipped with modern domestic equipment that provides smooth running production.

The preparation of enterprise financial reporting is the final stage, which forms a system of indicators characterizing the changes in assets and liabilities for a certain period and the economic activity of the enterprise in general [6]. That is, reporting is a source of information about the state of the entity in terms of final results.

It is worth considering where exactly in the reporting the information about the enterprise operating expenses is accumulated (Table 1).

\section{Table 1}

Information about operating expenses in the enterprise financial reporting

\begin{tabular}{|c|c|c|}
\hline Name of the form & Code and line name & Information \\
\hline 1 & 2 & 3 \\
\hline \multirow{2}{*}{$\begin{array}{l}\text { "Statement of } \\
\text { financial results" } \\
\text { ("Statement of } \\
\text { comprehensive } \\
\text { income") }\end{array}$} & $\begin{array}{l}2050 \text { "Cost of goods } \\
\text { sold (goods, works, } \\
\text { services)" }\end{array}$ & $\begin{array}{l}\text { The production cost of sold products (works and services) for } \\
\text { the reporting period, which consists of the production cost and } \\
\text { unallocated overhead fixed expenses. }\end{array}$ \\
\hline & $\begin{array}{l}2130 \\
\text { "Administrative } \\
\text { expenses" }\end{array}$ & $\begin{array}{l}\text { Expenses related to the management and maintenance of the } \\
\text { enterprise are presented: payroll of employees of the administration, } \\
\text { communication expenses, utilities and other administrative expenses. }\end{array}$ \\
\hline
\end{tabular}


Analysis of the enterprise operating expenses and ways of improvement of their accounting

Continuation of Table 1

\begin{tabular}{|c|c|c|}
\hline 1 & 2 & 3 \\
\hline & $\begin{array}{l}2150 \text { "Selling } \\
\text { expenses" }\end{array}$ & $\begin{array}{l}\text { Reflects information on expenses associated with the sale of products, } \\
\text { expenses of sales department, marketing services, advertising. }\end{array}$ \\
\hline & $\begin{array}{l}2180 \text { "Other } \\
\text { operating expenses" }\end{array}$ & $\begin{array}{l}\text { Information about other expenses arising in the operating activities } \\
\text { of the enterprise is displayed. }\end{array}$ \\
\hline & $\begin{array}{l}2500 \text { "Material } \\
\text { expenses" }\end{array}$ & $\begin{array}{l}\text { Information about the movement of materials for production, } \\
\text { overhead expenses, administrative and sales needs of the enterprise is } \\
\text { displayed. }\end{array}$ \\
\hline & $\begin{array}{l}2505 \text { "Labor } \\
\text { expenses" }\end{array}$ & $\begin{array}{l}\text { Information on the amounts of accrued payroll of employees } \\
\text { engaged operating activities of the enterprise is indicated. }\end{array}$ \\
\hline & $\begin{array}{l}2510 \text { "Deductions } \\
\text { for social measures" }\end{array}$ & $\begin{array}{l}\text { The amounts of the accrued single social contribution of production, } \\
\text { management and sales employees are displayed. }\end{array}$ \\
\hline & 2515 "Amortization" & $\begin{array}{l}\text { Information on the amounts of accrued depreciation for the reporting } \\
\text { period is disclosed. }\end{array}$ \\
\hline & $\begin{array}{l}2520 \text { "Other } \\
\text { operating expenses" }\end{array}$ & $\begin{array}{l}\text { The amount of operating expenses that were not indicated in other } \\
\text { lines of the report is indicated. }\end{array}$ \\
\hline \multirow{7}{*}{$\begin{array}{l}\text { "Notes to the } \\
\text { annual financial } \\
\text { statements" }\end{array}$} & $\begin{array}{l}440 \text { "Operating } \\
\text { lease of assets" }\end{array}$ & $\begin{array}{l}\text { Reflects information about expenses incurred in connection with the } \\
\text { operating lease and which is accumulated in account } 949 \text { "Other } \\
\text { operating expenses". }\end{array}$ \\
\hline & $\begin{array}{l}450 \text { "Operating } \\
\text { exchange rate } \\
\text { difference" }\end{array}$ & $\begin{array}{l}\text { Indicates information about the expenses associated with the } \\
\text { operating exchange rate difference. }\end{array}$ \\
\hline & $\begin{array}{l}460 \text { "Sale of other } \\
\text { current assets" }\end{array}$ & Information on the expenses of sales of inventories is disclosed. \\
\hline & $\begin{array}{l}470 \text { "Fines, } \\
\text { penalties, forfeits" }\end{array}$ & $\begin{array}{l}\text { Information on expenses, fines, penalties and forfeits incurred is } \\
\text { accumulated. }\end{array}$ \\
\hline & $\begin{array}{l}490 \text { "Other } \\
\text { operating expenses" }\end{array}$ & $\begin{array}{l}\text { Information on the expenses of changes in the value of assets at fair } \\
\text { value, research and development expenses, and expenses of buying } \\
\text { and selling foreign currency is displayed. }\end{array}$ \\
\hline & $\begin{array}{l}491 \text { "Deductions to } \\
\text { the provision for } \\
\text { doubtful debts" }\end{array}$ & $\begin{array}{l}\text { Indicates information on the expenses of doubtful and bad debts of } \\
\text { the enterprise. }\end{array}$ \\
\hline & $\begin{array}{l}492 \text { "Unproductive } \\
\text { expenses and losses" }\end{array}$ & $\begin{array}{l}\text { The expenses of depreciation of inventories, as well as shortages and } \\
\text { losses from damage to property are reflected. }\end{array}$ \\
\hline
\end{tabular}

Source: compiled by the authors on the material [10, 11, 12, 13]

Small business entities reflect information on operating expenses in the Statement of financial results (second form):

- line 2050 "Cost of goods sold (goods, works, services)" indicates information on the production cost of goods sold for the reporting period.

- line 2180 "Other operating expenses" displays information on the amounts of administrative expenses incurred, selling expenses, deductions for the creation of provision for doubtful debts, other operating expenses.

Therefore, financial statements are an important element of accounting that reflects financial condition and performance of the enterprise. Also, a wide range of stakeholders is interested in receiving such information.

The tax reporting also reflects the elements of operating expenses: wages, deductions for wages, as well as other tax payments that are accounted for as operating expenses.

1) The corporate income tax return reflects the pre-tax financial result, which is reduced by the amount of expenses incurred, including the cost of goods, works, services, overhead expenses, administrative expenses, marketing and other operating expenses. Also, in the event of tax 
differences, the amounts of expenses for the formation of the provision for doubtful debts are reflected, which will increase the pre-tax financial result.

2) In the form No. 1DF "Tax calculation of the amounts of income accrued (paid) in favor of taxpayers, and the amounts of tax withheld from them" information about the accrued income of the employee is reflected. The form is filled in on the basis of the credit balance of account 661 "Payroll Settlements", which reflects the accrual of wages and other payments to the employee. The tax (reporting) period for the Tax calculation in the form of No. 1DF is a quarter.

3) The report on the amounts of accrued payroll (income, cash and other benefits, allowances, compensation) of insured persons and the amount of accrued single contribution to the obligatory state social insurance presents the information on the accrual of single social contribution of different categories. The Report reflects information on the expenses incurred in relation to the accrued single social contribution. The reporting period of the Report is a month and (or) a year. The report is based on accounting documents with calculation of payments on which a single social contribution is accrued.

4) The ecological tax return is prepared by taxpayers defined in the Tax code of Ukraine. The tax return reflects the amounts of ecological tax liabilities. Also, depending on the type and method of emissions of pollutants, calculations of tax liabilities are formed.

Another type is management reporting, which is confidential, optional and intended for internal users. It satisfies the interests of owners, its purpose is to ensure effective management of internal departments, operational decisions at the level of structural units and so on. This is achieved by creating a system of additional internal or management accounting [5]. Management reporting is not regulated by law and is made, as a rule, by the chief accountant of the enterprise. It often details financial reporting and discloses information depending on the needs of internal users. This reporting is designed for effective management and elaboration of tactics and strategies for enterprise development.

According to the legislation of Ukraine, each business entity prepares financial statements as part of financial, tax and statistical reports. Forms of reporting are different for each of the entities, due to different forms of ownership, activities and industry specifics.

Thus, operating expenses are expenses that reflect the amount of resources used related to the production activities of the enterprise, as well as the expenses of management and marketing. The classification of such expenses is set at the enterprise according to the needs of users. Operating expenses are classified by economic elements and by items of calculation.

During difficult economic situation even more acute problem of cost management companies, information which is data analysis of various aspects of the cost [1].

To assess the financial condition of LLC "Lviv Center for Development and Protection of Economic Entities" it is necessary to analyze the dynamics of the enterprise's main economic indicators (Table 2) using financial reporting for 2018-2020.

Table 2

\section{Dynamics of the main economic indicators of the LLC "Lviv Center for Development and Protection of Economic Entities" for 2018-2019}

\begin{tabular}{|l|c|c|c|c|c|}
\hline \multicolumn{1}{|c|}{ Indicators } & 2018 & 2019 & 2020 & \multicolumn{2}{c|}{$\begin{array}{c}\text { Deviation } 2020 / 2018 \\
(+;-)\end{array}$} \\
\hline \multicolumn{1}{|c|}{1} & & & & $\begin{array}{c}\text { relative, } \\
\%\end{array}$ \\
\hline $\begin{array}{l}\text { Net revenue from sales of products (goods, works, } \\
\text { services), thousand UAH }\end{array}$ & 12179.70 & 15683.00 & 17889.00 & +5709.30 & +46.86 \\
\hline $\begin{array}{l}\text { Operating expenses, } \\
\text { thousand UAH, in particular: }\end{array}$ & 9612.96 & 11643.6 & 12494.95 & +2881.99 & +29.98 \\
\hline- cost of goods sold (goods, works, services) & 8654.90 & 10375.2 & 10980.60 & +2325.70 & +26.87 \\
\hline
\end{tabular}


Analysis of the enterprise operating expenses and ways of improvement of their accounting

Continuation of Table 2

\begin{tabular}{|l|c|c|c|c|c|}
\hline \multicolumn{1}{|c|}{1} & 2 & 3 & 4 & 5 & 6 \\
\hline - Administrative expenses & 505.20 & 572.3 & 620.10 & +114.90 & +22.74 \\
\hline - Selling expenses & 195.60 & 476.5 & 716.80 & +521.20 & +266.46 \\
\hline - Other operating expenses & 257.26 & 219.6 & 177.42 & -79.84 & -31.03 \\
\hline Expenses per hryvnia of sold products, kopecks / UAH & 79 & 70 & 70 & -9.00 & -11.39 \\
\hline Average number of employees, persons & 38 & 43 & 43 & +5 & +13.16 \\
\hline Average annual output per employee, thousand UAH & 320.50 & 416 & 416.00 & +95.50 & +29.80 \\
\hline Remuneration fund, thousand UAH & 1903.67 & 2171.12 & 2386.06 & +482.39 & +25.34 \\
\hline Average monthly payroll of one employee, UAH & 4174.71 & 4307.78 & 4624.15 & +449.44 & +10.77 \\
\hline Average annual value of fixed assets, thousand UAH & 3918.40 & 3698.22 & 2788.45 & -1129.95 & -28.84 \\
\hline Return on fixed assets, UAH / UAH & 3.11 & 2.81 & 6.42 & 3.31 & 106.39 \\
\hline Materials, thousand UAH & 6228.59 & 6337.16 & 6928.09 & +699.5 & +11.23 \\
\hline Material efficiency, UAH / UAH & 1.96 & 1.64 & 2.58 & +0.62 & +31.63 \\
\hline $\begin{array}{l}\text { Average annual value of assets, } \\
\text { thousand UAH }\end{array}$ & 11087.75 & 12598.52 & 15170.35 & +4082.60 & +36.82 \\
\hline Average balances of current assets, thousand UAH & 6933.95 & 8900.3 & 11939.00 & +5005.05 & +72.18 \\
\hline $\begin{array}{l}\text { The average value of equity, } \\
\text { thousand UAH }\end{array}$ & 9685.20 & 11239.15 & 13463.35 & +3778.15 & +39.01 \\
\hline Turnover ratio of current assets & 1.76 & 1.24 & 1.50 & -0.26 & $\mathrm{x}$ \\
\hline Coefficient of autonomy & 0.87 & 0.89 & 0.89 & +0.01 & $\mathrm{x}$ \\
\hline Current liabilities and provisions, thousand UAH & 1286.85 & 1359.37 & 1565.95 & +279.10 & +21.69 \\
\hline Total liquidity ratio & 5.39 & 6.55 & 7.62 & +2.24 & $\mathrm{x}$ \\
\hline Net profit, thousand UAH & 2457 & 4298.2 & 5172.3 & +2715.3 & +100.51 \\
\hline Net profitability of product sales, $\%$ & 20.18 & 27.41 & 28.91 & +8.73 & $\mathrm{x}$ \\
\hline Net return on assets (capital), & 22.16 & 34.11 & 34.09 & +11.93 & $\mathrm{x}$ \\
\hline
\end{tabular}

After analyzing the dynamics of the main economic indicators of LLC "Lviv Center for Development and Protection of Economic Entities" for 2018-2020 it is observed that the company operates efficiently, because the net profitability of sales in the reporting year compared to the previous year increased by $8.73 \%$, which was caused by an increase in net revenue from sales by 5709.3 thousand UAH. Also, net return on assets increased by $11.93 \%$, due to growth in net income by 2715.3 thousand UAH or $100.51 \%$.

Expenses per one hryvnia of operating income for the reporting year are 70 kopecks/UAH, and in the previous year - 79 kopecks/UAH, which indicates a reduction in expenses of the enterprise. There is a significant increase in salling expenses - by $266.46 \%$ or 521.2 thousand UAH, as well as an increase in the cost of goods sold (goods, works, services) - by $26.87 \%$ and administrative expenses by $22.74 \%$ (114.9 thousand UAH).

Given the fact that at the LLC "Lviv Center for Development and Protection of Economic Entities" the average number of employees in the reporting year increased for 5 people, the average monthly payroll of one employee also increased by $10.77 \%$ or UAH 449.44. During the analyzed period, the return on fixed assets increased rapidly by UAH 3.31 / UAH or $106.39 \%$.

Material costs in 2020 increased by $11.23 \%$, respectively, and material efficiency increases by $31.63 \%$. The growth of material efficiency is a positive phenomenon, as it indicates an increase in the number of manufactured products for each hryvnia used materials. The turnover ratio of current assets decreased by 0.26 , which indicates a decrease in the number of turnovers of assets for the analyzed period.

The coefficient of autonomy in the reporting year, compared to the previous year, increased by 0.01 . This is due to the fact that the growth rate of the average value of equity is much faster than the growth rate of current liabilities and provisions. Namely, the average value of equity increased by UAH 3,778.15 thousand. or $39.01 \%$ and a slight 


\section{O. Grytsay, M. Pankiv, D. Kut, G. Wojtan}

increase in current liabilities and provisions by UAH 279.10 thousand. or at $21.69 \%$.

Also, the total liquidity ratio indicates that the company has a liquid balance sheet because in the reporting year it is 7.62 . The increase in the total liquidity ratio by 2.24 is due to an increase in current assets and current liabilities. This is a positive trend for the enterprise, as it has a significant amount of free resources, which were formed due to its own sources. At first glance, we see that a significant part of current assets are stocks, as raw materials are the primary cost element for production.

Thus, LLC "Lviv Center for Development and Protection of Economic Entities" operates effectively, as evidenced by the above indicators. The enterprise increases its production, increases the number of employees in the reporting year compared to the previous one, which is a positive trend.

The analysis of the main economic indicators of the enterprise showed a decrease in expenses per hryvnia of revenue, and profitability indicators tend to increase, which characterizes the efficiency of the enterprise.

The main type of expenses at the enterprise is operating expenses. Their analysis involves assessing the dynamics, composition and structure. The basis of internal production planning is the analysis of operating expenses by items of calculation [1]. This allows you to determine the amount of expenses by type of product and place of origin, as well as the share of expenses accounted for by production, management, marketing and more.

It is advisable to analyze expenses of operating activities on these grounds, as well as to determine expenses for one hryvnia of production that will allow to track changes in operating expenses for a certain period. At LLC "Lviv Center for Development and Protection of Economic Entities" operating expenses are classified according to economic elements and calculation items, which allows to clearly define the purpose of expenses and their relationship with the production process, to assess them by place of origin.
Analysis of operating expenses by economic elements gives the possibility to determine the total cost of materials, labor and other production resources used, as well as allows to organize relevant control over the consumption of these expenses. Dynamics and structure of operating expenses of LLC "Lviv Center for Development and Protection of Economic Entities" for 20182020 is analyzed in Table 3.

Analysis of the dynamics of operating expenses by economic elements of LLC "Lviv Center for Development and Protection of Economic Entities" for 2018-2020 showed that overall operating expenses increased by 2283.32 thousand UAH or $21.67 \%$ due to growth of material expenses by UAH 693.59 thousand or $11.07 \%$, labor expenses by UAH 468.14 thousand, deductions for social measures by UAH 99.93 thousand and other operating expenses by 1056.39 thousand UAH or $126.23 \%$. However, amortization (depreciation) expenses decreased by UAH 34.73 thousand or $2.91 \%$.

Analysis of the structure of operating expenses by economic elements of LLC "Lviv Center for Development and Protection of Economic Entities" for 2018-2020 showed that the largest share is occupied by material expenses $(59.43 \%$ and $54.26 \%$, respectively, in the previous and reporting years), and the lowest - deductions for social measures $(3.67 \%$ in the previous and $3.80 \%$ in the reporting years). There is a tendency to reduce the share of material expenses (by $5.17 \%$ ) and amortization (depreciation) (by $2.29 \%$ ), as well as a significant increase in other operating expenses (by $6.82 \%$ ). Labor expenses also increased the share in the structure of operating expenses by economic elements, namely by $0.13 \%$.

The analysis of operating expenses of the enterprise by items of calculation allows to determine the target function of expenses, their relationship directly with the production process, as well as to estimate expenses by the type of product and place of use. The result of the dynamics and structure of operating expenses analysis by the items of calculation of LLC "Lviv Center for Development and Protection of Economic Entities" for 2018-2020 are presented in Table 4. 
Analysis of the enterprise operating expenses and ways of improvement of their accounting

Table 3

Dynamics and structure of operating expenses by economic elements LLC

"Lviv Center for Development and Protection of Economic Entities" for 2018-2020

\begin{tabular}{|c|c|c|c|c|c|c|c|c|c|}
\hline \multirow[b]{2}{*}{ Indicators } & \multicolumn{2}{|c|}{2018} & \multicolumn{2}{|c|}{2019} & \multicolumn{2}{|c|}{2020} & \multicolumn{3}{|c|}{ Deviation $2020 / 2018$} \\
\hline & 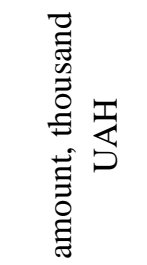 & 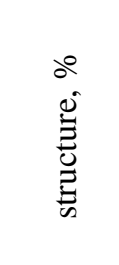 & 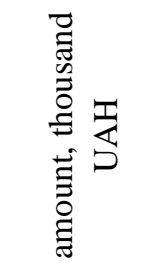 & 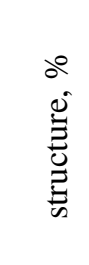 & 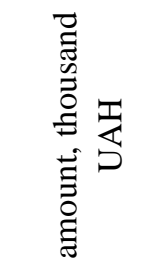 & 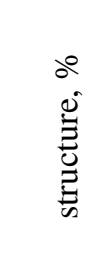 & 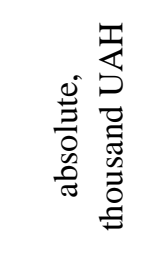 & 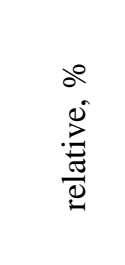 & 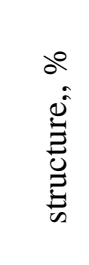 \\
\hline Material expenses & 6263.79 & 59.43 & 6482.07 & 57.61 & 6957.38 & 54.26 & +693.59 & +11.07 & -5.17 \\
\hline Labor expenses & 1855.91 & 17.61 & 1972.46 & 17.53 & 2324.05 & 18.12 & +468.14 & +25.22 & +0.52 \\
\hline $\begin{array}{l}\text { Deductions for } \\
\text { social measures }\end{array}$ & 386.99 & 3.67 & 408.74 & 3.63 & 486.92 & 3.80 & +99.93 & +25.82 & +0.13 \\
\hline Amortization & 1195.57 & 11.34 & 1187.35 & 10.55 & 1160.84 & 9.05 & -34.73 & -2.91 & -2.29 \\
\hline $\begin{array}{c}\text { Other operating } \\
\text { expenses }\end{array}$ & 836.86 & 7.94 & 1201.23 & 10.68 & 1893.25 & 14.77 & +1056.39 & +126.23 & +6.82 \\
\hline $\begin{array}{c}\text { Total operating } \\
\text { expenses }\end{array}$ & 10539.13 & 100.00 & 11251.85 & 100 & 12822.44 & 100.00 & +2283.32 & +21.67 & 0.00 \\
\hline
\end{tabular}

Dynamics and structure of operating expenses by costing items LLC

Table 4 “Lviv Center for Development and Protection of Economic Entities” for 2018-2020

\begin{tabular}{|c|c|c|c|c|c|c|c|c|c|}
\hline \multirow[b]{2}{*}{ Indicators } & \multicolumn{2}{|c|}{2018} & \multicolumn{2}{|c|}{2019} & \multicolumn{2}{|c|}{2020} & \multicolumn{3}{|c|}{ Deviation 2020-2018 (+,-) } \\
\hline & 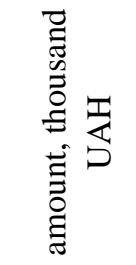 & 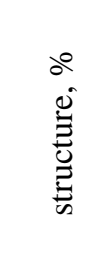 & 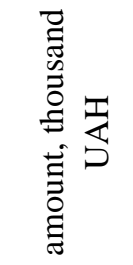 & 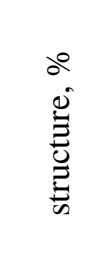 & 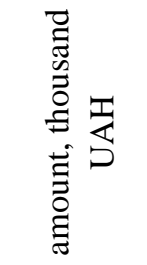 & 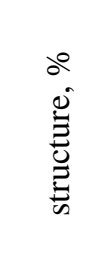 & 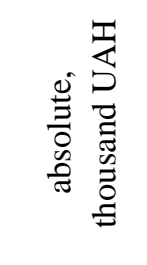 & $\begin{array}{l}\infty \\
\stackrel{0}{0} \\
\sum_{0}^{0} \\
0\end{array}$ & 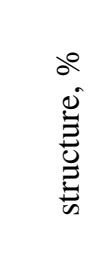 \\
\hline 1 & 2 & 3 & 4 & 5 & 6 & 7 & 8 & 9 & 10 \\
\hline $\begin{array}{c}\text { Cost of goods } \\
\text { sold (goods, } \\
\text { works, services) } \\
\text { (thousand UAH), } \\
\text { in particular: } \\
\end{array}$ & 8654.91 & 90.03 & 10375.2 & 89.11 & 10980.62 & 87.88 & +2325.71 & +26.87 & -2.15 \\
\hline - brick M-100 & 665.13 & 6.92 & 602.98 & 5.18 & 499.37 & 3.99 & -165.76 & -24.92 & -2.93 \\
\hline - brick M-125 & 6069.31 & 63.14 & 5879.98 & 50.50 & 5859.43 & 46.90 & -209.88 & -3.46 & -16.24 \\
\hline - brick M-150 & 1920.47 & 19.98 & 3892.24 & 33.43 & 4621.82 & 36.99 & +2701.35 & +140.66 & +17.01 \\
\hline $\begin{array}{c}\text { Administrative } \\
\text { expenses } \\
\text { (thousand UAH), } \\
\text { in particular: }\end{array}$ & 505.25 & 5.26 & 572.3 & 4.92 & 620.08 & 4.96 & +114.83 & +22.73 & -0.29 \\
\hline $\begin{array}{l}\text { - payroll of } \\
\text { employees and } \\
\text { accruals }\end{array}$ & 345.35 & 3.59 & 412.68 & 3.54 & 461.66 & 3.69 & +116.31 & +33.68 & +0.10 \\
\hline - amortization & 4.58 & 0.05 & 4.02 & 0.03 & 3.91 & 0.03 & -0.67 & -14.63 & -0.02 \\
\hline
\end{tabular}


Continuation of Table 4

\begin{tabular}{|c|c|c|c|c|c|c|c|c|c|}
\hline 1 & 2 & 3 & 4 & 5 & 6 & 7 & 8 & 9 & 10 \\
\hline $\begin{array}{c}\text { - communication } \\
\text { services }\end{array}$ & 3.34 & 0.03 & 3.13 & 0.03 & 3.03 & 0.02 & -0.31 & -9.28 & -0.01 \\
\hline - Other expenses & 151.98 & 1.58 & 152.47 & 1.31 & 151.48 & 1.21 & -0.50 & -0.33 & -0.37 \\
\hline $\begin{array}{c}\text { Selling expenses } \\
\text { (thousand UAH), } \\
\text { in particular: }\end{array}$ & 195.54 & 2.03 & 476.5 & 4.09 & 716.83 & 5.74 & +521.29 & +266.59 & +3.70 \\
\hline $\begin{array}{l}\text { - payroll of } \\
\text { employees and } \\
\text { accruals }\end{array}$ & 33.74 & 0.35 & 124.18 & 1.07 & 186.38 & 1.49 & +152.64 & +452.40 & +1.14 \\
\hline $\begin{array}{l}\text { - warehouse } \\
\text { maintenance }\end{array}$ & 55.15 & 0.57 & 108.2 & 0.93 & 193.54 & 1.55 & +138.39 & +250.93 & +0.98 \\
\hline $\begin{array}{c}\text { - transportation } \\
\text { expenses }\end{array}$ & 103.45 & 1.08 & 230.16 & 1.98 & 330.56 & 2.65 & +227.11 & +219.54 & +1.57 \\
\hline - other expenses & 3.20 & 0.03 & 13.96 & 0.12 & 6.35 & 0.05 & +3.15 & +98.44 & +0.02 \\
\hline $\begin{array}{c}\text { Other operating } \\
\text { expenses } \\
\text { (thousand UAH), } \\
\text { in particular: }\end{array}$ & 257.26 & 2.68 & 219.6 & 1.89 & 177.42 & 1.42 & -79.84 & -31.03 & -1.26 \\
\hline $\begin{array}{c}\text { - taxes, fees and } \\
\text { other mandatory } \\
\text { payments }\end{array}$ & 167.27 & 1.74 & 143.26 & 1.23 & 121.64 & 0.97 & -45.63 & -27.28 & -0.77 \\
\hline - consulting fees & 3.34 & 0.03 & 3.1 & 0.03 & 2.28 & 0.02 & -1.06 & -31.74 & -0.02 \\
\hline $\begin{array}{c}\text { - expenses of } \\
\text { information } \\
\text { support }\end{array}$ & 6.09 & 0.06 & 5.6 & 0.05 & 4.04 & 0.03 & -2.05 & -33.66 & -0.03 \\
\hline - other expenses & 80.56 & 0.84 & 67.64 & 0.58 & 49.46 & 0.40 & -31.10 & -38.60 & -0.44 \\
\hline $\begin{array}{c}\text { Total operating } \\
\text { expenses }\end{array}$ & 9612.96 & 100.00 & 11643.6 & 100 & 12494.95 & 100.00 & +2881.99 & +29.98 & 0.00 \\
\hline
\end{tabular}

Analysis of the dynamics of operating expenses on the items of calculation of LLC "Lviv Center for Development and Protection of Economic Entities" for 2018-2020 showed that overall expenses increased by $29.98 \%$ or at 2881.99 thousand UAH. There is a significant increase in the cost of goods sold, including bricks M-150 by 2608.31 thousand UAH or $156.65 \%$. Administrative expenses increased in 2020 compared to 2018 by $22.73 \%$ due to an increase in labor expenses for employees of the administration by 116.31 thousand $\mathrm{UAH}$. The tendency to increase is also observed for selling expenses (labor expenses and related charges, expenses of transportation of products, expenses associated with the maintenance of the warehouse) in the amount of 521.29 thousand UAH or $266.59 \%$. Other operating expenses decreased in the reporting year compared to the previous year by $31.03 \%$ or by UAH 79.84 thousand.
The result of the analysis of the structure of operating expenses by cost items of LLC "Lviv Center for Development and Protection of Economic Entities" for 2020 is shown in Fig. 1.

Analysis of the structure of operating expenses of LLC "Lviv Center for Development and Protection of Economic Entities" for 2018-2020 allowed us to see that the largest share is occupied by the cost of goods sold (goods, works, services). Administrative expenses in the analyzed period increased only due to payroll growth. Sales expenses increased significantly, which indicates that the analyzed company began to increase attention in this area.

The generalizing stage of the analysis of operating expenses is to determine the effectiveness of expenses per hryvnia of products value. The analysis is carried out on such basic indicators as operating expenses per one hryvnia of revenue 
Analysis of the enterprise operating expenses and ways of improvement of their accounting

from operating activities (performance indicator of the enterprise), cost of goods sold per one hryvnia of net revenue from sales, as well as the profitability of operating activity.
Analysis of the expenses of operating activities effectiveness of LLC "Lviv Center for Development and Protection of Economic Entities" for 20182020 is given in the form of Table 5.

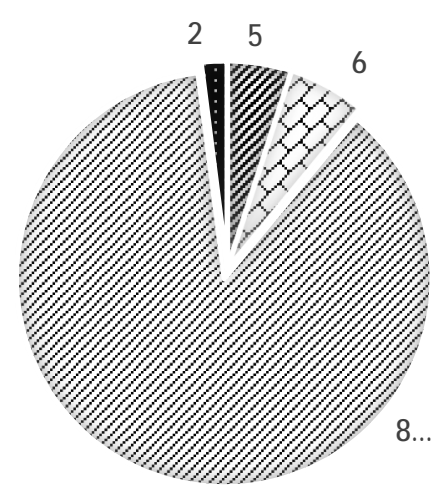

* Administrative expenses

selling expenses

$\backsim$ Cost of goods sold

- Other operating expenses

Fig. 1. Structure of operating expenses of LLC "Lviv Center for Development and Protection of Economic Entities" for 2020

\section{Dynamics of cost indicators per hryvnia of product cost LLC "Lviv Center for Development and Protection of Economic Entities" for 2018-2020}

\begin{tabular}{|c|c|c|c|c|c|}
\hline \multirow{2}{*}{ Indicators } & \multirow{2}{*}{2018} & \multirow{2}{*}{2019} & \multirow{2}{*}{2020} & \multicolumn{2}{|c|}{ Deviation 2020/2018 } \\
\hline & & & & absolute, $(+,-)$ & relative, $\%$ \\
\hline \multicolumn{6}{|c|}{ Initial indicators } \\
\hline $\begin{array}{l}\text { Other operating revenue, thousand } \\
\text { UAH }\end{array}$ & - & - & 0,10 & $+0,10$ & $\mathrm{x}$ \\
\hline Operating expenses, thousand UAH & 9612.96 & 11643.6 & 12494.95 & +2881.99 & +29.98 \\
\hline $\begin{array}{l}\text { in particular: } \\
\text { - cost of goods sold (goods, works, } \\
\text { services); }\end{array}$ & 8654.90 & 10375.2 & 10980.62 & +2325.72 & +26.87 \\
\hline - Administrative expenses & 505.20 & 572.3 & 620.08 & $+114,88$ & +22.74 \\
\hline - Selling expenses & 195.60 & 476.5 & 716.83 & +521.23 & +266.48 \\
\hline - Other operating expenses & 257.26 & 219.6 & 177.42 & -79.84 & -31.03 \\
\hline $\begin{array}{l}\text { Net revenue from sales of products, } \\
\text { thousand UAH }\end{array}$ & 12179.70 & 15683.00 & 17889.00 & +5709.30 & +46.88 \\
\hline $\begin{array}{l}\text { Profit from operating activities, } \\
\text { thousand UAH }\end{array}$ & 2566.74 & 4039.4 & 5394.05 & +2827.31 & +110.15 \\
\hline \multicolumn{6}{|c|}{ Analytical indicators } \\
\hline $\begin{array}{l}\text { Operating expenses per one hryvnia } \\
\text { of revenue from operating activities, } \\
\text { kopecks / UAH }\end{array}$ & 79 & 74 & 70 & -9 & -11.50 \\
\hline $\begin{array}{l}\text { Cost of goods sold per one hryvnia } \\
\text { of net revenue from sales, kopecks / } \\
\text { UAH }\end{array}$ & 71 & 66 & 61 & -10 & -13.62 \\
\hline Profitability of operating activity, $\%$ & 21.07 & 25.76 & 30.15 & +9.08 & $\mathrm{x}$ \\
\hline
\end{tabular}




\section{Vol. 8, No. 1, 2021}

Table 5 shows that for 2018-2020 there is a decrease in the cost of goods sold per one hryvnia of net revenue from sales by 10 kopecks/UAH or $14.08 \%$, which is a positive phenomenon, as the capacity of the enterprise has increased. There is also a reduction in operating expenses per one hryvnia of revenue from operating activities by 9 kopecks/UAH. Such changes are due to the growth rate of net revenue from sales $(46.88 \%)$ over operating expenses $(26.87 \%)$.

At the same time, the profitability of operating activities increased by $9.08 \%$, which indicates a positive trend in changes in the operating activities of LLC "Lviv Center for Development and Protection of Economic Entities". This is due to an increase in net revenue from sales of products by 5709.6 thousand UAH, as well as an increase in operating profit by 2827.14 thousand UAH or $110.15 \%$.
LLC "Lviv Center for Development and Protection of Economic Entities" uses only the 9th class of accounts "Business expenses" to reflect expenses.

The system of cost calculation at the enterprise involves the use of the process method with the elements of standard costing, and for individual orders - job-order method also with the elements of standard costing. The list of processes is determined depending on the technology and taking into account the feasibility of planning, accounting and calculating production cost for each object. Direct material costs are served as the basis for distribution of variable and distributed fixed manufacturing overheads for each cost object.

The enterprise does not have approved in the accounting policy calculation items. Therefore, it is necessary to introduce changes and establish such list and structure of calculation items (Table 6).

Proposals on the composition of the items of production costs calculation

\begin{tabular}{|c|c|c|}
\hline Costs & Title of articles & Composition of articles \\
\hline \multirow{3}{*}{ 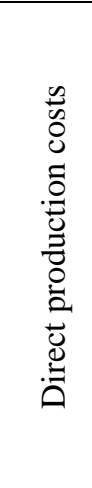 } & Direct material costs & $\begin{array}{l}\text { - Raw materials. } \\
\text { - Spare parts. } \\
\text { - Recyclable waste. } \\
\text { - Semi-finished products of own production. } \\
\text { - Auxiliary materials. }\end{array}$ \\
\hline & Direct labor costs & $\begin{array}{l}\text { - Wage (salary). } \\
\text { - Compensation and other payments to employees. }\end{array}$ \\
\hline & Other direct costs & $\begin{array}{l}\text { - Deductions for social measures. } \\
\text { - Depreciation of fixed assets. } \\
\text { - Amortization of intangible assets. } \\
\text { - Other direct costs }\end{array}$ \\
\hline \multirow[b]{2}{*}{ 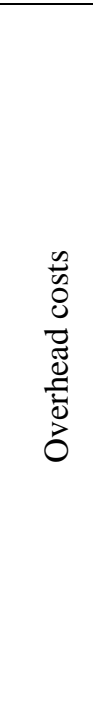 } & Variable overhead costs & $\begin{array}{l}\text { - Training costs. } \\
\text { - The cost of maintaining the production process. } \\
\text { - Work in progress shortage. } \\
\text { - Shortages and losses from damage of property in the shops within } \\
\text { the norms of natural loss. } \\
\text { - Repair of fixed assets. }\end{array}$ \\
\hline & Fixed overhead costs & $\begin{array}{l}\text { - The cost of improving technology and organization of production. } \\
\text { - Salary of the shop management staff. } \\
\text { - Deductions for social measures and medical insurance of the } \\
\text { management of shops, sections. } \\
\text { - Expenses for business trips of shop staff. } \\
\text { - Expenses for labor protection, safety. } \\
\text { - Depreciation of fixed assets. } \\
\text { - Amortization of intangible assets. } \\
\text { - Costs for heating, lighting, water supply. } \\
\text { - Repair of fixed assets for general production purposes. }\end{array}$ \\
\hline
\end{tabular}




\section{Analysis of the enterprise operating expenses and ways of improvement of their accounting}

Source: compiled by the authors on the material [1, 13, 14]

Also in the accounting policy of LLC "Lviv Center for Development and Protection of Economic Entities", it is necessary to provide information on the accounting for transport and procurement expenses. For example, it is advisable to separate sub-account 2011 "Transport and procurement expenses for raw materials and supplies", if such raw materials and supplies are purchased. Therefore, it is necessary to distinguish relevant accounts for transport and procurement expenses for each homogeneous group of inventories that the enterprise buys. Such expenses, defined using the average interest method, will be attributed to the value of inventories that have been disposed of. These costs will be written off later, in the correspondence of disposal of the relevant tangible assets.

It is also established that the current accounting policy does not fully disclose and regulate the accounting for operating expenses. To avoid negative results associated with the unspecified organization of accounting for operating expenses, it is proposed to introduce a list of direct production and overhead costs to the cost calculation items. In addition, the suggestions regarding the accounting for transport and procurement expenses were presented.

LLC "Lviv Center for Development and Protection of Economic Entities", in compliance with the Instruction for the Chart of Accounts application, has developed current chart of accounts with disclosed analytics to accounts related to production, as well as expense accounts in general. The enterprise has no secondary production and therefore account 231 "Main production" is the only account, which reflects all types of expenses that are included in the cost of production. Subaccount 901 "Cost of finished products sold" records the production cost of sold finished products. The formation of the cost in terms of expenses is shown in Fig. 2.

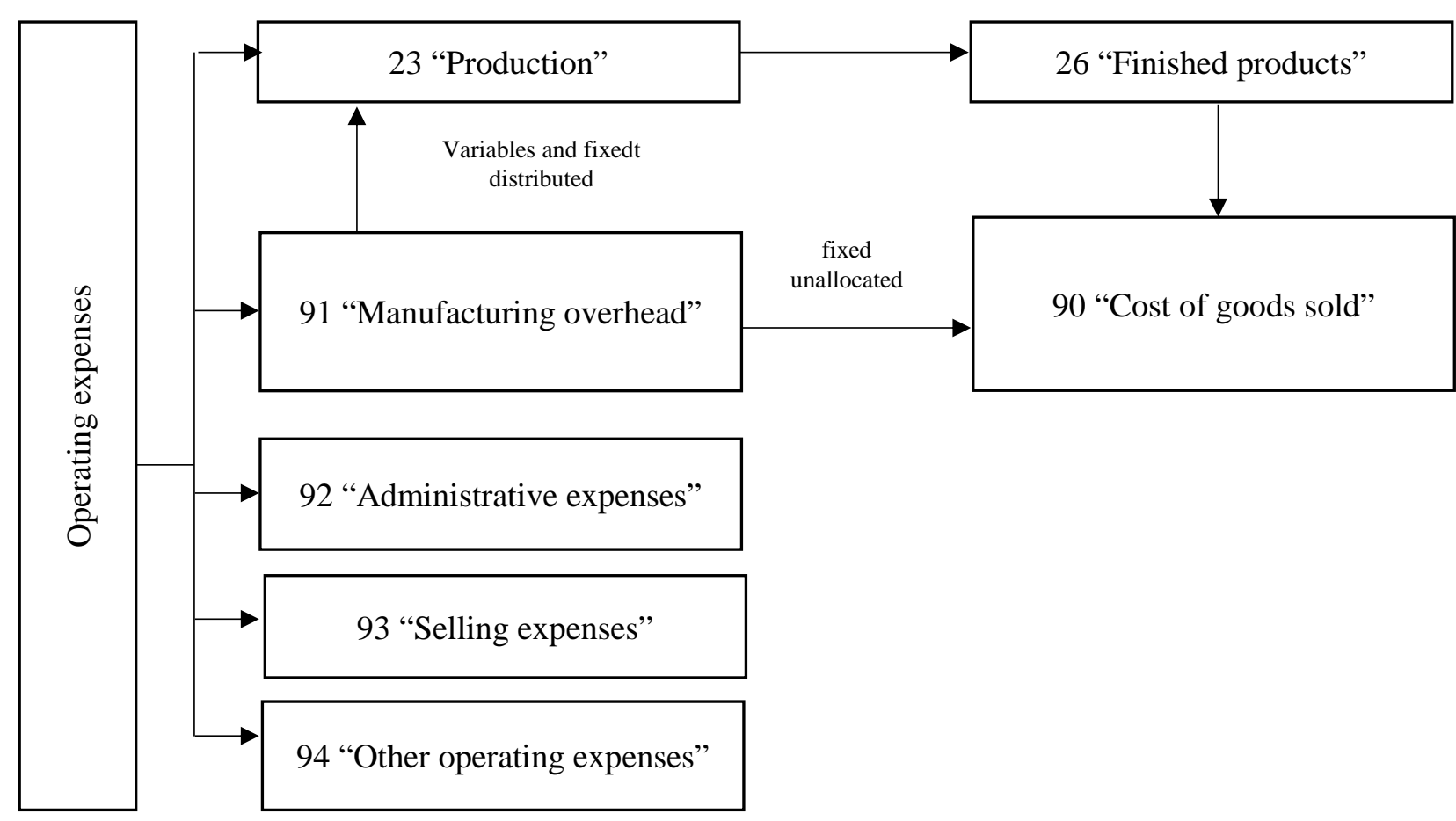

Fig. 2. Accounting for operating expenses at $L L C$

"Lviv Center for Development and Protection of Economic Entities"

Source: compiled by the authors

It is proposed to reflect enterprise operating expenses in accounts 231 "Brick production unit", 901 "Cost of finished products sold", 91
"Manufacturing overhead", 92 "Administrative expenses", 93 "Selling expenses", 949 "Other operating expenses". 


\section{O. Grytsay, M. Pankiv, D. Kut, G. Wojtan}

The enterprise uses standard forms of source documents for accounting for operating expenses, as well as develops and approves its self-developed forms of source documentation. Analytical accounting at the enterprise is imperfect that determines the need to open subsidiary accounts to accounts 91 "Manufacturing overhead", 93 "Selling expenses", 94 "Other operating expenses". This would enable the enterprise management to make effective decisions aimed at operating expense optimization.

Analytical accounting on account 231 "Brick production unit" at LLC "Lviv Center for Development and Protection of Economic Formations" is conducted in order to accumulate information about the expenses of brick production unit by expense items.

Account 91 "Manufacturing overhead" has no sub-accounts. The debit of the account reflects the increase in expenses and the credit - their write-off to the financial result. Manufacturing overhead costs associated with the organization of production are accumulated on the relevant account and then are distributed to account 231 "Brick production unit" and account 90 "Cost of goods sold".

The basis of distribution at analyzed enterprise is direct material costs. Reflection in the accounting of overhead costs without analytical grouping complicates the perception of information about costs and hampers effective in decision-making.

For the purposes of internal (management) accounting it is necessary to introduce appropriate changes in the Order on the accounting policy that imply the introduction of expense grouping in the context of relevant items. The proposals of such grouping on the example of account 91 "Manufacturing overhead" is given in Table 7.

Table 7

\section{Proposals for manufacturing overhead grouping for LLC "Lviv Center for Development and Protection of Economic Entities"}

\begin{tabular}{|c|c|c|c|c|c|}
\hline \multicolumn{4}{|c|}{ Financial Accounting } & \multicolumn{2}{|r|}{ Internal accounting } \\
\hline $\begin{array}{l}\text { Code of } \\
\text { account }\end{array}$ & Account name & $\begin{array}{l}\text { Sub-account } \\
\text { number }\end{array}$ & $\begin{array}{l}\text { Name of the group by } \\
\text { types of expenses }\end{array}$ & $\begin{array}{l}\text { Cost item } \\
\text { code }\end{array}$ & Name of cost item \\
\hline \multirow{8}{*}{91} & \multirow{8}{*}{ 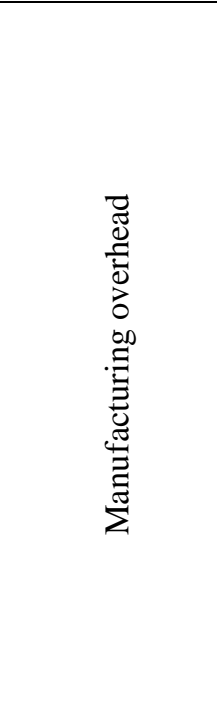 } & \multirow{5}{*}{911} & \multirow{5}{*}{$\begin{array}{l}\text { The object of main } \\
\text { production }\end{array}$} & 9111 & $\begin{array}{l}\text { Manufacturing overhead costs } \\
\text { of clay storage }\end{array}$ \\
\hline & & & & 9112 & $\begin{array}{l}\text { Manufacturing overhead costs } \\
\text { of forming department }\end{array}$ \\
\hline & & & & 9113 & $\begin{array}{l}\text { Manufacturing overhead costs } \\
\text { of tunnel dryers }\end{array}$ \\
\hline & & & & 9114 & $\begin{array}{l}\text { Manufacturing overhead costs } \\
\text { of batch department }\end{array}$ \\
\hline & & & & 9115 & $\begin{array}{l}\text { Manufacturing overhead costs } \\
\text { of the tunnel furnace }\end{array}$ \\
\hline & & \multirow{2}{*}{912} & \multirow{2}{*}{$\begin{array}{l}\text { Maintenance and } \\
\text { operation of machinery } \\
\text { and equipment }\end{array}$} & 9121 & $\begin{array}{l}\text { Depreciation of fixed assets for } \\
\text { general production purposes }\end{array}$ \\
\hline & & & & 9122 & $\begin{array}{l}\text { Other equipment maintenance } \\
\text { costs }\end{array}$ \\
\hline & & 913 & $\begin{array}{l}\text { Other manufacturing } \\
\text { overhead }\end{array}$ & & \\
\hline
\end{tabular}

Source: compiled by the authors

The dependence of economic security on qualitatively-formed accounting and analytical support for such purposes is substantiated $[8,15-$ 18]. The authors prove that nowadays, there are inconsistencies of the current accounting with the enterprise economic security requirements.

Account 92 "Administrative expenses" reflects operating expenses that are not taken into account for determining the cost of production. It has 
analytical (subsidiary) accounts that specify the origin of expenses. Sub-account 921 "Administrative expenses of the enterprise" reflects the salary and charges of administration departments' staff, depreciation of fixed assets used for administrative purposes, etc.

The expenses for economic security of the enterprise is a type of expenses that fully corresponds to the essence of administrative expenses, because they are aimed at supporting the main enterprise activities, are permanent and in no way related to the volume of production [17]. It is important to take into accuont the nature and origin of expenses associated with the activities that ensure the enterprise security. Therefore, the use of subaccount 923 "Expenses on economic security of the enterprise" to account 92 "Administrative expenses" with analytics would enhance convenience and speed of retrieval of information, in particular:

- 923.1 - Expenses associated with the establishment of economic security system;

- 923.2 - Expenses for maintaining the staff of economic security service;

- 923.3 - Expenses for creating the information base of economic security;

- 923.4 - Other expenses related to the activity of economic security service.

It is worth considering how the increase in economic security expenses occurs by presenting the correspondence of accounts (Table 8).

Table 8

Correspondence of accounts of economic security expenses accounting for LLC "Lviv Center for Development and Protection of Economic Entities"

\begin{tabular}{|l|c|c|c|l|}
\hline \multirow{2}{*}{ The content of business transaction } & \multicolumn{2}{|c|}{$\begin{array}{c}\text { Correspondence } \\
\text { of accounts }\end{array}$} & \multirow{2}{*}{ Source documents } \\
\cline { 2 - 3 } & Debit & Credit & \\
\hline \multicolumn{3}{|c|}{ Expenses for maintaining the staff of economic security service } \\
\hline The basic and additional salaries of the staff are accrued & 923.2 & 661 & Timesheet, Letters for a fee \\
\hline Single social contribution has been accrued & 923.2 & 651 & Summary statement of deductions \\
\hline $\begin{array}{l}\text { Expenses related to staff training to improve skills are } \\
\text { reflected }\end{array}$ & 923.2 & 685 & Act of work performed \\
\hline $\begin{array}{l}\text { Depreciation of technical means of ensuring economic and } \\
\text { personnel security is accrued }\end{array}$ & 923.2 & 131 & $\begin{array}{l}\text { Statement of depreciation of } \\
\text { fixed assets }\end{array}$ \\
\hline $\begin{array}{l}\text { Expenses associated with advisory recommendations for } \\
\text { staff skills are reflected }\end{array}$ & 923.2 & 685 & Act of work performed \\
\hline $\begin{array}{l}\text { Expenses on maintaining general-purpose vehicles in relation to } \\
\text { the activities of the security service }\end{array}$ & 923.2 & 205,131 & $\begin{array}{l}\text { Check, Act of work performed, } \\
\text { Route list }\end{array}$ \\
\hline
\end{tabular}

Source: compiled by the authors on the material [8, 15, 16, 17]

Today, in the post-industrial economy, the crucial condition for obtaining a financial result is not only to ensure the production process, but its selling, in particular, bringing it to the consumer.

Under such conditions, enterprises increase the expenses incurred for the development of management systems that support the main production. Such systems include enterprise management, marketing, research and development, logistics and more. One of the most important roles in improving the efficiency of the enterprise is played by marketing expenses.
The main purpose of marketing expenses is to create and maintain a positive image of the organization, maximize the use of its resources to determine the direction of movement and meet market needs for products and services.

Therefore, there is a need to develop effective approaches to managing marketing expenses in the enterprise based on the use of appropriate accounting and analytical support.

Such approaches should allow to manage these expenses, to draw conclusions about the effectiveness and efficiency of their incurrence to achieve the objectives of the activity, given the 


\section{O. Grytsay, M. Pankiv, D. Kut, G. Wojtan}

specifics and characteristics of marketing expenses, the factors influencing the level and behavior of such expenses.

The requirements for current accounting provided by the current legislation do not ensure the conditions for thorough accounting for any marketing expenses on one control account. Marketing expenses are the element of current operating expenses, in particular selling expenses. The proposed classification of marketing expenses should form the basis for nomenclature of accounts construction, which will allow to move from the description of retrospective facts of economic life to forecasting the situation in the market [19].

At present, LLC "Lviv Center for Development and Protection of Economic Entities" reflects in account 93 "Sales expenses" only the expenses of transportation of finished products, as well as the cost of maintenance of finished product warehouse.

Selling expenses do not have specific details, so the company should divide the expenses according to the following analytics:

- 931 "Expenses of transportation of finished products";

- 932 "Expenses for maintenance of finished product warehouse";

- 933 "Other selling expenses".

Account 931 should take into account the expenses associated with the calculation of payroll for employees engaged in the transportation of products, repair of cars, trucks, by means of which the products are delivered, and other expenses associated with the transportation of finished products.

Sub-account 932 will be used to reflect expenses of the warehouse where the products are stored: payroll of the employee of such warehouse, write-off of materials used for the warehouse and more.

Sub-account 933 will take into account the expenses of creating and operating a marketing service (for remuneration and bonuses for staff, for logistics and information support of marketing services, training of marketing staff), expenses for market research, advertising expenses and more.

Account 94 "Other operating expenses" is also often used at the LLC "Lviv Center for Development and Protection of Economic Entities" and has subsidiary account 949 "Other operating expenses".

LLC "Lviv Center for Development and Protection of Economic Entities" widely uses expense account 949 "Other operating expenses" in which it is also proposed to indicate the following analytics:

- 949.1 "Expenses related to information, consulting, auditing services";

- 949.2 "Expenses for information support, Internet services, periodicals";

- 949.3 "Expenses for preferential pensions";

- 949.4 "Expenses for taxes, fees";

- 949.5 "Other operating expenses".

Thus, the task of analytical subsidiary accounts is to disclose detailed information on the occurrence of expenses by structural units, by the type of activity, by usage. They enable the collecting of necessary information for enterprise performance analysis. In the process of accounting LLC "Lviv Center for Development and Protection of Economic Entities" uses subsidiary accounts that satisfy the requirements of internal users.

\section{Conclusions and prospects for further research}

The paper presents the results of analysis of accounting and analytical information on the operating expenses at LLC "Lviv Center for Development and Protection of Economic Entities". Operating expenses are an important economic category considering that they account for the largest share of the total enterprise expenses. It is investigated that parameters of classification and accounting for enterprise expenses are determined by economic, organizational, technological conditions, as well as the competence of managers and, accordingly, their needs for management information. Relevant classification of expenses contributes to the effectiveness of expense management and accounting for that supports achieving target business objectives.

The considered characteristic of LLC "Lviv Center for Development and Protection of Economic Entities" operation allowed to define the goal, the purposes and the basic type of activity - brick production by burning clay. The accounting policy of the enterprise is not perfect regarding the reflection of the enterprise operating expenses. Therefore, it 


\section{Analysis of the enterprise operating expenses and ways of improvement of their accounting}

is proposed to approve the cost calculation items, as well as to establish methods of distribution of transport and procurement expenses.

The analysis of the main economic indicators shows that the the enterprise operates efficiently, as the net profitability of product sales in 2020 compared to 2018 increased by $8.73 \%$, which was caused by an increase in net revenue from sales by 5709.3 thousand UAH.

Also, the total liquidity ratio indicates that the enterprise has liquid balance sheet, as in analyzed period this indicator was equal 9.23. This shows that the enterprise has enough of its own current assets to cover current liabilities. Despite the positive growth trend of economic indicators, the average monthly payroll of an employee at LLC "Lviv Center for Development and Protection of Economic Entities" is low.

Analytical subsidiary accounts provide the possibility to collect necessary information to analyze the enterprise performance. Accounting for operating expenses with introduction of proposed subsidiary accounts ensure detailed analysis of these expenses in order to determine their effectiveness, necessity and feasibility of their incurrence.

\section{References}

1. Deriy V. A. (2010). Normatyvno-pravove zabezpechennya obliku $i$ kontrolyu vytrat ta dokhodiv pidpryyemstv [Normative-legal provision of accounting and control of expenses and revenues of enterprises]. Zhytomyr: ZhDTU. International Collection of Scientific Works. Series: Accounting, control and analysis. Vol 2 (17), 77-83. [in Ukrainian].

2. Didorenko T. V. (2015). Sutnist' vytrat yak ob'yekta bukhhalters'koho obliku [The essence of expenses as an object of accounting] Young scientist No. 1 (1), 78-81. [in Ukrainian].

3. Ovcharuk, V. V. (2018). Systemy administruvannia $v$ upravlinni pidpryiemstvamy: pobudova ta zastosuvannia $z$ urakhuvanniam yevrointehratsiinykh protsesiv [Administration systems in enterprise management: construction and application taking into account European integration processes]. Lviv: Halytska vydavnycha spilka, 276 [in Ukrainian].

4. Kostyrko, R. O. (2010). Kontrol $i$ analiz v systemi upravlinnia ekonomichnym potentsialom hospodariuiuchoho sub'iekta: metodolohiia ta orhanizatsiia [Control and analysis in the economic potential management system of an economic entity: methodology and organization.]. Luhansk: Skhidnoukrainskyi universytet im. V. Dalia [in Ukrainian].

5. Milash I. V. (2015) Stratehichne upravlinnya vytratamy pidpryyemstv rozdribnoyi torhivli [Strategic cost management of retail enterprises] Monograph. Kharkiv: Kharkiv State University of Food and Trade. 284 p. [in Ukrainian].

6. Denisyuk O. M. (2015). Analiz operatsiynykh vytrat mashynobudivnykh pidpryyemstv na prykladi Vinnyts'koyi oblasti [Analysis of operating expenses of machine-building enterprises on the example of Vinnytsia region] Agrosvit No. 22, 44. [in Ukrainian].

7. Pavelko O. V. (2012). Dokhody i vytraty osnovnoyi diyal'nosti budivel'nykh pidpryyemstv u systemi obliku ta kontrolyu: monohrafiya. [Income and expenses of the main activity of construction companies in the system of accounting and control] Monograph. Rivne, 236 p. [in Ukrainian].

8. Hnylytska, L. (2014). Vidobrazhennia vytrat, pov'iazanykh $z$ diialnistiu iz zabezpechennia bezpeky pidpryiemstva $v$ systemi bukhhalterskoho obliku ta vidkrytoi zvitnosti [Display costs related to enterprise security activities in accounting and open reporting]. Bukhhalterskyi oblik $i$ audyt. 4, 39-46 [in Ukrainian]

9. Shatalkin, I. A. (2014). Problemyi izmereniya transaktsionnyih izderjeki sposobyi ih preodoleniya [Problems of transaction costs' measurement] Scientists notes of Petrozavsk State University. 1, 108-110. [in Russian]

10. Tyvonchuk O. I. (2016). Tendencje rozwoju wspolczesnej rachunkowosci finansowej i zarzadczej [Tendencies of development of modern financial and management accounting]. Monograph / O. I. Tyvonchuk, H. P. Mudrynets, O. V. Ryabkova, Yu. M. Simchich, Z. M. Skibinskaya, T. S. Udalova, O. I. Grytsay, M. O. Kmet, T. T. Hryniv, I. O. Ivanyshyn, M. Ya. Yastrubsky, M. I. Yukhman, R. L. Khomyak, S. Ya. Chudiyovych, R. Y. Zheliznyak, Yu. O. Gandziuk, O. I. Poznyakova, Yu. A. Kosovska. Lublin, Poland: Wydzial Ekonomiczny UMCS282 p. [in Ukrainian]

11. Oleksiv, I. (2014). Theoretical and practical approaches to identification of stakeholder interests of the company. Lviv: Economics, Entrepreneurship, Management. Lviv Polytechnic National University. 1 (1), 31-35

12. Bratsenyuk Maria (2019). Oblik ta finansy: suchasni vektory rozvytku [Accounting and finance: modern vectors of development]. Monograph / 


\section{O. Grytsay, M. Pankiv, D. Kut, G. Wojtan}

M. Bratsenyuk, M. V. Olshanska, O. I. Vasylyshyn, O. I. Grytsay, M. M. Pankiv, L M. Pylypenko, S. R. Kholodnytska, Z. Skybinska, S. Vovkiv, V. Smigur, N. M. Voskalo, Ya. V. Mezhyrytska, T. I. Voskresenska, T. M. Ivasyuk, I. Y. Yaremko, V. A. Guzandrova, A. I. Yasinska, K. V. Martyniuk. Lublin, Poland: Wydzial Ekonomiczny UMCS. 107 p. [in Ukrainian]

13. Vytraty [Costs]. (1999, December 14). Polozhennia (standart) bukhhalterskoho obliku N16. Nakaz Ministerstva finansiv Ukrainy [National accounting principles (standard) (NAP(S)) Order of the Ministry of Finance of Ukraine ] No 860/4153. Retrieved from https://zakon.rada.gov.ua/laws/ show/z0027-00 [in Ukrainian]

14. Babich I., Sheludchenkova A., Borkovska V., Tsegelnik N., Grytsay O. (2020). Accounting and analysis of equipment overhaul costs. Estudios de Economia Aplicada. Vol. 38, No. 4, 1-9.

15. Liashenko, O. M. (2015). Kontseptualizatsiia upravlinnia ekonomichnoiu bezpekoiu pidpryiemstva [The conceptualization of economically secure enterprise management]. Retrieved from http://old2.niss.gov.ua/content/articles/files/ lyashenko_1_druk-43fc7.pdf [in Ukrainian].

16. Pogorelov, Y. S. \& Bulcot H. V. (2014). Pryntsypy ta skladovi kontroliu yak elementu systemy ekonomichnoi bezpeky pidpryiemstva [Principles and components of control as an element in an enterprise economic security system]. Khmelnitsky:
Accounting and analytical support for formation of enterprise economic security costs and their Visnyk Khmelnytskoho natsionalnoho universytetu. Ekonomichni nauky, 3, 39-41. [in Ukrainian].

17. Grytsay O., Havran M. (2020). Accounting and analytical $s$ upport for formation of enterprise economic security expenses and their controlling process. Economics, Entrepreneurship, Management. Vol. 7, No. 1, 75-83.

18. Qi, Z., Shi, Z., Li, F., Zhang, H., Liu, H. \& Feng J. (2016). Development and application of the security stability control management system. Power System Protection and Control. 44 (1), 122127.

19. Grytsay O. I., Kmet M. O. (2018). Formuvannya informatsiynoyi bazy pro vytraty na marketynh $v$ strukturi pokaznykiv zvitnosti pidpryyemstva [Formation of information base on marketing expenses in the structure of enterprise reporting indicators]. Bulletin of the National University of Water Management and Environmental Sciences. Economic sciences. Vol. 4 (80), 180-193 [in Ukrainian]. 